\title{
Enhancing Adoption Studies: The Case of Residential Stormwater Management Practices in the Midwest
}

\author{
Dong Won Shin and Laura McCann
}

\begin{abstract}
This study explores factors affecting adoption of two stormwater management practices, rain gardens and rain barrels. Mail survey data from Columbia, Missouri indicate adoption rates of 3.12 percent (rain gardens) and 7.47 percent (rain barrels). This unique dataset enables us to distinguish among nonadopters using knowledge levels, and to investigate the effect of practice-specific barriers. Clustered multinomial logistic regressions reveal serious gardeners are more likely to adopt both practices. Specific barriers differ by practice and type of nonadopter. Adding practice-specific barriers increased pseudo $\mathrm{R}^{2}$ values from 0.12 to 0.22 for rain gardens and from 0.13 to 0.26 for rain barrels.
\end{abstract}

Key Words: adoption, rain barrels, rain gardens, residential best management practices, stormwater runoff

JEL codes: 03, Q25, Q52

There has been a trend towards increasing urbanization in the United States (U.S. Department of Agriculture 2013, United Nations 2014). Between 1982 and 2000 , developed land increased by 43 million acres or 58 percent (U.S. Department of Agriculture 2013). With increasing urbanization, there is a decrease in wetlands and an increase in impervious surface area such as buildings, parking lots, roads, and driveways. As an example, from 1990 to 2000, the impervious surface area within the Chesapeake Bay Watershed increased by 61 percent, primarily due to the conversion of agricultural lands

Dong Won Shin is a research fellow at Korea Environment Institute, Sejong, Republic of Korea. Laura McCann is a professor at the Department of Agricultural and Applied Economics, University of Missouri. Correspondence: Laura McCann - Department of Agricultural and Applied Economics - 200 Mumford Hall - University of Missouri - Columbia, MO 65211 USA - Phone +01 573-882-1304 -Email: mccannl@missouri.edu.

This project was supported by National Integrated Water Quality Grant Program number 110.C (Award 2012-03652). The authors also acknowledge the support of the Missouri Agricultural Experiment Station. The authors would like to thank the two reviewers for constructive comments that enabled us to improve the paper. In addition, we appreciate the help of Bob Broz, Brad Fresenburg, and Mike Heimos in early stages of the research, as well as the valuable advice of Suh Won Lee.

The views expressed are the authors' and do not necessarily represent the policies or views of any sponsoring agencies.

Agricultural and Resource Economics Review 47/1 (April 2018) 32-65

(C) The Author(s) 2017. This is an Open Access article, distributed under the terms of the Creative Commons Attribution-NonCommercial-ShareAlike license (http://creativecommons.org/licenses/ by-nc-sa/4.0/), which permits non-commercial re-use, distribution, and reproduction in any medium, provided the same Creative Commons licence is included and the original work is properly cited. The written permission of Cambridge University Press must be obtained for commercial re-use. 
to urban uses (Jantz, Goetz, and Jantz 2005). In turn, increasing impervious surface area affects both the quantity and quality of stormwater runoff.

Increased stormwater runoff results in high peak flows, channel erosion, and flooding; these changes in stream hydrology result in the deterioration of aquatic habitats in urban streams (Booth and Jackson 1997, Wang et al. 2001, Brabec, Shulte, and Richards 2002). In addition, impervious surfaces convey nutrients and pesticides into local streams; this is associated with algal blooms, eutrophication, loss of biological diversity, and contaminated groundwater (Law, Band, and Brove 2004, Gilinsky et al. 2009). Thus, improving urban stormwater management in residential areas can be critical to aquatic habitat and water quality.

Potential solutions to these problems can be found in the literature on green infrastructure or low-impact development (LID). Practices such as rain gardens, rain barrels, drought-tolerant native plantings, buffer strips around waterways, and permeable pavements have been proposed to improve water quality, restore aquatic habitats, and control flooding at a fairly low cost (U.S. EPA 2003, 2007). Our study examines adoption of two of these practices - rain gardens and rain barrels - explained in depth in the Application section. Briefly, a rain garden is a man-made depression using plants to filter and infiltrate stormwater collected from impervious surfaces such as roofs and parking lots, thus improving water quality in nearby waterways and recharging groundwater $\mathrm{Li}$ and Davis 2009). Rain barrels are devices designed to collect stormwater runoff from roofs, which can then be used to water a garden or lawn. They can also reduce flooding in yards and decrease the volume of stormwater runoff (Jennings et al. 2012). Rain gardens are costlier to install and generally attractive, while rain barrels are relatively easy and inexpensive to install and enable use of rain water on-site but are less attractive.

Adoption rates for these practices are currently quite low. In the Chesapeake Bay, Newburn et al. (2014) found that 2.3 percent of households had adopted rain gardens, while 7.6 percent had adopted rain barrels. A better understanding of the factors affecting adoption of these practices is needed so policy makers and educators can use the information to increase adoption rates. It may also enable improved design of the practices themselves. The literature on residential adoption of stormwater best management practices (BMPs), discussed in the literature review, is currently quite small. Most of the work on factors affecting adoption of BMPs has been conducted with farmers rather than households.

In this study we explore the factors affecting adoption of these two stormwater management practices in an urbanizing watershed in central Missouri using a mail survey (effective response rate of 44 percent). This research adds to the sparse literature on residential adoption of stormwater management practices. In addition to examining individuals' demographic characteristics and attitudes, a contribution of this study is examination of practice-specific perceptions of barriers to adoption. These additional factors can both improve the explanatory power of the model, which is generally low for adoption studies, and provide specific information to guide practice 
design, policies, and educational efforts. Our unique dataset also enables us to distinguish between different types of nonadopters. Some people are not aware of the practices at all, some have minimal knowledge, and others consider themselves knowledgeable but have not adopted the practice. Combined with data on practice-specific barriers, this allows us to more directly examine the linkage between knowledge about a practice and adoption. Finally, the current study compares the factors influencing adoption of rain gardens and rain barrels, which have different attributes.

The empirical results confirm that those who are interested in gardening, concerned about the environment, and knowledgeable about the implementation of practices are more likely to adopt the practices. The results reveal that different perceived barriers exist for the two practices. For rain gardens, if respondents have a physical limitation, they are less likely to adopt even if they know the practice well. On the other hand, for rain barrels, time required and lack of equipment are the main barriers to adoption. In addition, nonadopters who are knowledgeable are quite different from other nonadopters. Finally, including variables relating to perceptions of an innovation's barriers can improve model performance.

While our study focuses on a specific watershed and specific practices, insights regarding practice-specific barriers and types of nonadopters can inform the design of future adoption studies. Specific and detailed information on barriers can improve 1) the design of practices by engineers and hydrologists to overcome barriers, 2) policy interventions, and 3) the targeting of educational programs. In addition, because our adoption rates of 3.1 percent for rain gardens and 7.5 percent for rain barrels are similar to those in the Chesapeake Bay area (Newburn et al. 2014), these results may apply to other areas.

\section{Literature Review}

Previous literature examining determinants of BMP adoption has primarily focused on agricultural producers. Few studies have examined factors influencing the adoption of stormwater management practices by households, even though the U.S. Environmental Protection Agency has acknowledged that residents' non-point-source pollution is a leading source of water quality degradation (Gilinsky et al. 2009). The studies examined in this section were ones in which the dependent variable was actual adoption of stormwater management practices such as rain gardens (Shaw et al. 2011), rain barrels (Bakacs et al. 2013), and lawn care management practices (Blaine et al. 2012, Brehm, Pasko, and Eisenhauer 2013, Martini and Nelson 2014). We also examine other studies that explore households' demand or preference for rain gardens and/or rain barrels (e.g. Thurston et al. 2010, Ando and Freitas 2011, Londoño Cadavid and Ando 2013) and for stormwater management practices (e.g. Kaplowitz and Lupi 2012). Findings from the literature are used to develop the hypotheses discussed in the Conceptual Framework section. 
In the literature, demographic characteristics are consistently shown to have a significant effect on adoption of residential environmental BMPs. This information can be used in targeting specific groups in outreach or marketing strategies. For example, Laroche, Bergeron, and Barbaro-Forleo (2001) identified consumers who are willing to pay more for environmentally friendly products by investigating the demographic, psychological and behavioral profiles of consumers. Income level of the household consistently shows a positive effect on adoption (e.g. Ando and Freitas (2011) for rain barrels, Blaine et al. (2012) for chemical use, Brehm, Pasko, and Eisenhauer (2013) for BMPs). However, the effects of level of education and age of homeowners on the probability of adopting practices are less clear. Increased level of education tends to increase the probability of adoption of specific practices such as appropriate disposal of grass clippings (Brehm, Pasko, and Eisenhauer 2013), but there are also studies that find an insignificant relationship between level of education and adoption of stormwater management practices such as rain barrels (Ando and Freitas 2011). Age is included in analyses to represent the homeowners' experience positively and innovativeness negatively (Rogers 2010), but the few empirical studies on these practices find insignificant relationships (e.g. Brehm, Pasko, and Eisenhauer (2013) on lawn care BMPs, Ando and Freitas (2011) on rain barrels).

Characteristics of a home can also influence adoption. Geographical location may influence homeowners' preference for lawn care management (Brehm, Pasko, and Eisenhauer 2013). Because urban residents experience higher levels of water and air pollution, they are typically more concerned about the environment than rural residents (Van Liere and Dunlap 1980). On the other hand, rural respondents are less likely to use chemicals on their lawns since neighborhood factors can motivate people to intensively manage urban landscapes (Blaine et al. 2012). Homeownership positively affects adoption of rain barrels because homeowners have greater incentives to make long-term investments (Ando and Freitas 2011), and landlords may restrict changes to the home.

In addition to demographic variables, behavioral and attitudinal factors can affect an individual's preferences. For example, those who are more interested in gardening are more likely to adopt lawn care practices and rain barrels (Newburn et al. 2014) because they may be more knowledgeable about lawn management and may gain more utility from the practices. Gardeners are also more concerned with the appearance of their yard (Purchase 1997). Similarly, households' water management or yard management practices, such as watering habits and using a lawn care service, can have effects on BMP adoption (Martini et al. 2015).

Environmental knowledge and attitudes are key factors affecting behavioral intentions to adopt stormwater management practices (Dietz, Clausen, and Filchak 2004, Jorgensen and Syme 2000). Knowledge-based factors such as knowledge about recommended BMPs and awareness of a watershed 
management plan or other planning efforts may increase adoption of residential BMPs in urbanizing watersheds (Swann 2000, Bakacs et al. 2013). Households with more knowledge of lawn management are more likely to adopt lawn management BMPs (Brehm, Pasko, and Eisenhauer 2013, Martini and Nelson 2014). Ando and Freitas (2011) also show that awareness of effects of a specific practice has a positive effect on adoption of rain barrels. Positive attitudes towards the environment in general and trust in information from environmental groups can also affect decision-making about innovation adoption. Households' trust in certain information providers may cause them to follow these providers' suggestions regarding water management, lawn maintenance, and landscape choice, (Varlamoff et al. 2001). In addition, neighbors' use of the practice can positively affect adoption of practices such as rain barrels (Ando and Freitas 2011). Individuals might have heterogeneous preferences over a given level of an environmental quality attribute such as intense flooding or severe drought. However, Ando and Freitas (2011) find that adoption of rain barrels is not significantly associated with local flooding frequency.

Perceptions about innovations are considered in adoption studies (Rogers 2010). The obvious factors affecting adoption are perceived benefits and costs associated with the innovation. For example, a primary reason for having rain barrels is to save water (Bakacs et al. 2013), and availability of a cost saving strategy such as cost sharing or discount programs can encourage households to adopt rain gardens (Shaw et al. 2011).

The importance of complexity is highlighted in the literature because complexity can increase the time to install and use the practice (Rogers 2010). If an innovation is complex, it will increase the effort and time required to learn about the equipment, installation, and performance of the innovation, and to install it appropriately. Thus, complexity may increase the risk of technical failure. However, the results of the study by Shaw et al. (2011) indicate insignificant relationships between adoption of rain gardens and the practice being time consuming or complex. In addition, individuals' physical ability to implement practices may be related to adoption (Rogers 2010).

Perceptions about appearance and concern about property value can affect the adoption of residential BMPs. For example, households who believe that lawn care management may improve their property values are more likely to use lawn care BMPs (Blaine et al. 2012). Households consider the appearance of a rain garden in their adoption decision (Shaw et al. 2011). Also, compatibility with needs for stormwater management practices in a rural residential area is positively related to willingness to adopt (Armstrong and Stedman 2012).

Beyond financial benefits and costs, lower risk and uncertainty associated with the practices may matter (Cary, Webb, and Barr 2001). People who experience basement flooding have an intention to pay to reduce flood frequency (Londoño Cadavid and Ando 2013). Trialing a practice or seeing a 
demonstration before installing, can provide information that reduces uncertainty about the benefits of the practice or decreases information costs (Pannell et al. 2006, Rogers 2010). Related to risk and uncertainty, a lack of information about the details of practices such as 'how to install and use a rain barrel' is a barrier to adoption of specific innovations because individuals must know how to implement particular environmental practices before they can intentionally act (e.g., Varlamoff, Florkowski, and Latimer 2002, Brehm, Pasko, and Eisenhauer 2013, Martini and Nelson 2014).

In addition, modeling the adoption decision as dichotomous (adoption vs. nonadoption) implicitly assumes that each individual is fully informed about the new technology (Feder, Just, and Zilberman 1985). However, nonadopters might become adopters if necessary information is provided, while others do not become adopters due to their strong risk aversion, attitudes toward the new technology, or expectations of new technology. Therefore, several studies with farmers include limited information in their adoption decision models. For example, Saha, Love, and Schwart (1994) analyzed factors affecting Texas dairy producers' technology-adoption intensity conditioned on awareness of the new technology. Dimara and Skuras 2003 proposed a two-stage model (information acquisition and evaluation) concerning adoption of organic cultivation in Greece. These studies imply that dichotomous adoption models can overestimate the adoption rate (Saha, Love, and Schwart 1994) or can be misspecified (Dimara and Skuras 2003) because of the full-information assumption.

Rather than using a dichotomous model, distinguishing between types of adopters can provide additional insights. For example, Läpple and Rensburg (2011) found that there are significant differences in economic and noneconomic explanatory factors between groups of early, medium, and late adopters of organic farming. However, Barham et al. (2004) used Wisconsin panel data on dairy farmers to show that early and late adopters of an agricultural biotechnology (rBST), as well as disadopters, are quite different from nonadopters and thus suggest that those who had not adopted within seven years after the technology was introduced were unlikely to adopt. It is likely that most Wisconsin dairy farmers would have heard of the technology because it was controversial (Barham et al. 2004). That may not be the case for stormwater management practices that are unlikely to attract media attention or affect livelihoods. Awareness of the existence of an innovation can be a starting point to form the intention to adopt (Rogers 2010). Awareness, coupled with indicators of attitudes and constraints, is important because it is part of the reasoning process that motivates behavior change (Prokopy et al. 2009). Distinguishing between types of nonadopters based on their level of knowledge of the practice may thus provide useful insights regarding factors affecting adoption and the potential impact of educational programs, compared to a dichotomous dependent variable. This study uses a unique dataset to distinguish among types of nonadopters.

The literature shows that both characteristics of households and households' perceptions about practices affect adoption of stormwater management 
practices. Although many adoption studies focus on the individuals' characteristics, individuals' perceptions about specific practices have been relatively neglected in the literature. This is unfortunate because research on practice-specific perceptions of barriers to adoption can be used to improve the design of practices and enable more effective policies and educational programs.

The literature on adoption also indicates that the explanatory power of the models is generally low (Knowler and Bradshaw 2007). This might be due to employing the binary logit or probit models that commonly have low pseudo$\mathrm{R}^{2}$ values compared to OLS regression models (Hosmer and Lemeshow 2004), or because the adoption models are missing important explanatory variables. Few adoption studies examine the improved explanatory power due to incorporation of additional variables, although Marra, Hubbell, and Carlson (2001) show improvement in measures of goodness of fit due to adding on-farm profit information into the model of Bt cotton adoption. In this study, we examine the impact of including a suite of practice-specific perception variables in addition to the conventional variables used in adoption studies.

\section{Conceptual Framework}

To apply adoption theory in economic studies, random utility models are employed on individual choices (Walker and Ben-Akiva 2002, Greene 2003). This model assumes that individuals, subject to their budget constraints, select the alternative resulting in higher utility, which is affected by many observed factors such as households' characteristics and unobserved factors such as individual preferences. Because the true utility function is unknown, unobserved latent factors are treated as random with a normal distribution assumption (Greene 2003). We assume that each household faces a set of discrete and exclusive choices, and decision-maker $i$ chooses $j$ if $U_{i j}>U_{i k} \forall k \neq j$.

Households' adoption decisions are based on a range of factors. From the literature review, these factors can be divided into the following four categories: homeowner personal characteristics (PC), yard management behavior (YM), awareness and attitudes toward environment and neighbors (AE), and perceptions about the practices (PP). Thus, the random utility function $U($.$) is assumed to be a function of these factors. The empirical$ specification includes a random factor $\varepsilon$, which has a normal distribution. Thus, we have

$$
\mathrm{U}_{i}=U(\mathrm{PC}, \mathrm{YM}, \mathrm{AE}, \mathrm{PP}, \varepsilon) .
$$

Specific hypotheses to be tested are based on the literature.

Because households interested in gardening had a significantly higher-thanaverage likelihood of adoption of environmental practices (Purchase 1997, 
Newburn et al. 2014), we hypothesize that households spending more time gardening or in outdoor activities in their yard will be more likely to adopt stormwater management practices.

Positive environmental attitudes and awareness of environmental effects of practices will be related to adoption (Ando and Freitas 2011), and if people have stronger attitudes they are more confident in their decisions (Stern 2000). Also, trust in information providers can be important to decision making about innovation adoption (Varlamoff et al. 2001). Thus, we hypothesize that households with more knowledge about the environment and trust in local environmental groups will be more likely to adopt both practices.

As discussed above, complexity and the degree to which an activity is timeconsuming may be related. We expect that those who perceive a practice as requiring more work are less likely to adopt it. Concerns about the appearance of property and about property value can limit the adoption of BMPs that affect the appearance of the yard or house (Shaw et al. 2011). Therefore, individuals who perceive appearance of the practices as a barrier are expected to be less likely to adopt.

Different risk or uncertainty implications of practices will be an important consideration. In particular, homeowners who doubt the effectiveness of the practices will be less likely to adopt, and those who have water in their basements will be more likely to adopt.

People cannot engage in environmentally beneficial behaviors if they do not know the details of how to engage in those behaviors. In particular, limited knowledge about specific stormwater management practices is also a strong factor limiting adoption. We hypothesize that households with less knowledge about specific practices will be less likely to adopt them. However, it is also the case that adopters should develop knowledge about the practices as they implement them, so for the typical dependent variables used in adoption studies, i.e., adopters versus nonadopters, the causality related to knowledge is not clear.

Finally, we hypothesize that including perceptions about specific attributes and barriers will increase the explanatory power, compared to including only the typical demographic and attitude variables used in adoption studies. This has the added advantage of providing specific information to be used in the development of practice design, policy, and educational efforts.

\section{Application}

\section{Research Site}

The Hinkson Creek watershed, which comprises an area of approximately 90 square miles in Columbia, Missouri, is an example of a typical urbanizing watershed. Columbia is the fourth largest city in Missouri, with a population of 108,500 and a metro area population of 173,083 , according to the 2010 
census. This represents an increase of almost 19 percent since 2000, while the population of Missouri only increased by 7 percent during this period (U.S. Census Bureau, 2010). Similar to other urbanizing watersheds, Hinkson Creek has experienced problems associated with increased stormwater flows and pollutant loads due to changes in land use and land cover. As a result, the watershed was added to the Clean Water Act (CWA) 303d list of impaired waters in 1998. The Hinkson Creek Watershed Management Plan (2010) indicates severe problems such as more frequent floods and lower base flow, increased soil erosion, pollution from urban storm water runoff, and degraded habitat for aquatic organisms. Because these problems can result from residential as well as commercial sources, adoption of stormwater management practices by homeowners in the Hinkson Creek watershed can contribute to improving this situation. A previous study (Baumer 2007) focused on environmental attitudes and awareness in the watershed, rather than actual implementation of stormwater management practices.

\section{Stormwater Management Practices}

A rain garden is a man-made depression that uses plants to filter pollutants and infiltrate stormwater collected off impervious surfaces such as roofs and parking lots, thus improving water quality in nearby waterways, delaying peak flow, recharging groundwater, and decreasing erosion (Dietz and Clausen 2005, Dietz 2007). The plants use some of this captured runoff and associated nutrients (Shaw et al. 2011). The native plants often used in rain gardens need less water and less fertilizer than grassed lawns. They also have lower maintenance requirements, provide habitat for wildlife, and are generally attractive. Rain gardens thus provide both on-site and off-site benefits. However, the initial investment is relatively high, some plants might take two or three years to establish, and more maintenance in the first few years is expected. Rain garden costs will vary depending on the soil conditions, and the size, density, and types of plants used. According to the Low Impact Development Center (2015a), residential rain gardens average about $\$ 3$ to $\$ 4$ per square foot to plan and install if done by the homeowner and about $\$ 10$ to $\$ 15$ per square foot if done by a landscaper. Given a typical size of 200 square feet, a rain garden would thus cost \$2000-3000, installed. Maintenance of a rain garden involves checking for sediment build-up once every season (Amiralaei et al. 2012) as well as weeding. Compared to the ongoing costs of lawn maintenance, rain gardens can be economically feasible because of their low maintenance costs, once established (Craig et al. 2008).

Rain barrels are devices designed to impart higher water retention capacity to residential lots by collecting stormwater runoff from roofs, which can later be used to water a garden or lawn. They thus decrease the volume of stormwater runoff and can also reduce flooding in yards. Storing rainwater for later use on gardens and lawns also helps recharge groundwater (Jennings et al. 2012, Litofsky and Jennings 2014). In addition, rain barrels can help reduce water 
pollution because stormwater runoff often picks up pollutants such as oil and animal waste, and transports them to waterways. However, rain barrels capture a fairly minimal volume of stormwater, and poor construction or maintenance can result in mosquitoes (Bakacs et al. 2013). Rain barrels are a relatively low-cost stormwater practice but maintenance and management are required (City of Chicago 2015). Although costs vary by manufacturer, the cost of a 50-gallon rain barrel is between $\$ 90$ and $\$ 120$ or homeowners can make their own for as little as $\$ 20$ according to Low Impact Development Center (2015b). According to the Rainfall Harvest Calculator (Gardeners 2015), just a half inch of rain falling on an average 1,000-square-foot house rooftop will yield over 300 gallons of water, which implies that multiple rain barrels, as well as overflow provisions, would be needed. Rain gardens and rain barrels are thus relatively inexpensive and low maintenance and offer both private and environmental benefits.

\section{Methods}

A mail survey was conducted in Columbia, Missouri in spring of 2014 using the Dillman methodology (Dillman 2011). A mail survey method was employed because it avoids problems of interviewer bias, can be done at the respondent's convenience, increases response rates, and also covers a larger percentage of people than telephone surveys or internet surveys, thus reducing bias (Hudson et al. 2004). A random sample of 2000 residents was obtained from Survey Sampling International, a large international provider of sampling as well as data analysis, using ZIP codes primarily including the City of Columbia but also adjacent suburban and rural areas (65201, 65202, and 65203). Sampling by ZIP code can be beneficial for simplicity and potentially causes less clustering of the sample (Staab and Iannacchione 2003).

The survey focused on detached single-family homes. The person in the household most responsible for lawn care was asked to complete the survey. The questionnaires were designed to learn whether households have adopted stormwater management practices, specifically rain gardens and rain barrels, and how the household's characteristics, social context, environmental attitudes, yard care practices, and perceptions of each practice affected the adoption decision. This study included several modified survey questions to measure environmental attitudes (Baumer 2007), and lawn care practices (Meyer, Behe, and Heilig 2001). The survey also used specific questions from the Social Indicators for Planning and Evaluation System (SIPES) to measure perceptions of each practice (Genskow and Prokopy 2009). SIPES is a system developed by a team of Midwest researchers for collecting consistent social indicator data to evaluate the effectiveness of water quality projects and to develop incentive and educational programs (Prokopy et al. 2009).

Researchers often use pre-tests to improve the survey; this involves sending the survey to a limited number of people and examining the results. Another method, respondent debriefing, involves incorporating responses of people 
after they take the survey to gain a better understanding of how respondents interpret questions (DeMaio, Rothgeb, and Hess 1998). Two groups of a dozen volunteers took the survey, and we discussed the survey instrument with them afterwards. We modified the final survey in response to feedback from that process.

Dillman (2011) suggests many techniques designed to improve response rates, including customizing letters, using multiple mailings (survey packets and postcard reminders), and providing the rationale for the need for responses. A pre-notice postcard was sent in early February 2014, a few days before the survey. Then, the survey was sent out with a cover letter, a postage-paid return envelope and a magnet with a photo of Hinkson Creek and an Extension website. Ten days later, a reminder postcard was sent, followed three weeks later by the second complete survey package, asking households to participate. Before calculating the response rate, people who had moved or were deceased (200), and people for whom the survey was not applicable (such as having no lawn (27)) were subtracted. Of the 1773 questionnaires mailed to valid addresses, 783 were completed and returned, for an effective response rate of 44.1 percent. This is higher than the response rate in recent adoption studies about stormwater management practices, (e.g., 25.3 percent for Brehm et al. 2013 and 17.2 percent for Newburn et al. 2014), which would tend to reduce nonresponse bias.

All variables were constructed from the answers provided by the survey respondents. The dependent variables, use of rain gardens and rain barrels, were multinomial variables $(1=$ Never heard of it, $2=$ Somewhat familiar with it but not using it, $3=$ Know how to use it but not using it, and $4=$ Currently use it). For demographic variables, annual household income was divided into five categories; less than $\$ 24,999, \$ 25,000-\$ 49,999, \$ 50,000$ $\$ 74,999$ (base category), $\$ 75,000-\$ 99,999$ and more than $\$ 100,000$. Age group variables included four categories: 18-31 years, 31-45 years, 46-60 years (base category), and over 60 years. A dummy variable for male (vs. female) gender was used. The variable of homeownership was not included in the model because no respondents who were renting indicated adoption of rain gardens. Location variables included living in the city of Columbia (base category), suburban areas, and rural areas.

For household behavior variables, four gardening time categories (average hours a month during the growing season (March to November)) were combined to reflect two subcategories, 0-10 hours (base category), and greater than 10 hours. Frequency of watering the lawn included four categories: as needed to keep it green, infrequently in summer, only in severe drought, and never water. The last two were combined into a low watering variable, and the first two were combined for the base. The lawn care service variable was coded as $0=$ No use of any services, or $1=$ Use of lawn care service such as mowing, fertilizing, and using pesticides.

Knowledge of the watershed concept, which was measured by asking about the term watershed, includes three categories: Know what it means, I have 
heard of it but I'm not sure what it means, and Never heard of it. The last two responses were combined into the base category. Households' environmental attitudes are proxied by the degree of trust in environmental groups as information providers; responses included: Not at all, Slightly, Moderately, and Very much. The first three options were combined into the base category in the regression. A variable of attitude about neighbors was measured by their level of agreement with the statement "It is important to me that my neighbors think I have a nice lawn," using a Likert scale $(1=$ Strongly disagree to $5=$ Strongly agree). Responses 1,2 , or 3 were combined into a base category and responses of 4 or 5 form the agree dummy variable. Variables regarding perceptions of climate change were obtained by asking respondents to rate their concerns about more frequent intense rains as well as longer dry periods and drought using a Likert scale. The responses were treated the same as for the previous variable.

Variables for perceptions of each practice's characteristics or barriers to adoption were obtained by asking respondents to rate the degree to which various factors limited their ability to implement rain gardens and rain barrels, using a Likert scale $(1=$ Not at all, $4=\mathrm{A}$ lot $)$ suggested by Genskow and Prokopy (2009). These variables relate to: effort to install and maintain the practice (cost, time, and physical/ health issues), concern about appearance of the practice, compatibility with features of their property, lack of equipment, uncertainty about water quality benefits, inability to see a demonstration, water problems in their basement, and knowledge about installing it. For each variable, responses of 3 and 4 are combined into an agree category and responses of 1 and 2 are combined into the base category.

Given the low frequency of adoption of rain gardens (3.1 percent) and rain barrels (7.5 percent), there are many 0 observations for households who did not adopt the practices if we simply use a binary model for adopters versus nonadopters. Nevertheless, our unique dataset allows us to distinguish between three types of nonadopters, based on their awareness of the two specific practices: Never heard of it, Somewhat familiar with it but not using it, and Know how to use it but not using it. Therefore, the multinomial logit (MNL) model is employed to analyze the survey data, comparing the three distinct types of nonadopters to the base category, adopters of rain gardens and rain barrels.

The MNL model is widely used in adoption decision studies because it can explain the differences between adopters and nonadopters by simultaneously estimating binary logits for all comparisons among the outcome categories (Long 1997). In this case, each household chooses one of the mutually exclusive alternatives characterized by the dependent categorical variable. Hence, we specify the MNL as follows (Greene 2003):

$$
\operatorname{Pr}\left(y_{i}=j\right)=\frac{\exp \left(\mathbf{x}_{i} \boldsymbol{\beta}_{j}\right)}{\sum_{k=1}^{4} \exp \left(\mathbf{x}_{i} \boldsymbol{\beta}_{k}\right)} i=1, \ldots, n \text { and } j=1,2,3,4
$$


where $y_{i}$, the dependent variable, represents the choice made by household $i$ and takes the values,

$$
y_{i}=\left\{\begin{array}{l}
1, \text { if "never heard of it and not adopt" } \\
2, \text { if "know somewhat but not adopt" } \\
3, \text { if "know well but not adopt" } \\
4, \text { if currently using it", }
\end{array}\right.
$$

and where $\mathbf{x}_{i}$ is a set of explanatory variables.

Our base category is "currently using it;" therefore, in our model a positive parameter means that the relative probability of being in one of the nonadopter categories increases relative to the probability of choosing to adopt specific practices. (This is opposite from the interpretation of typical models where the reference category is nonadoption.)

Adoption decisions for rain gardens are likely not made independently of rain barrels and observations in the same group or clusters that have similar characteristics are more likely correlated with each other (Agresti 2003) ${ }^{1}$. Thus, the single equation multinomial logit method may not be efficient because it ignores the correlation between the error terms of the underlying stochastic utility function (Greene 2003). For this reason, we employed the cluster option, which takes into account the intra-cluster correlation by calculating the robust standard error because we cannot treat observed outcomes as independently and identically distributed within a cluster for statistical analysis (Agresti 2003). The robust standard errors are calculated based on the Huber-White method, also known as the sandwich method, to correct within-cluster dependence by providing consistent estimates of the covariance matrix for parameter estimates even when the errors exhibit heteroskedasticity (Agresti 2003). We use a cluster robust estimation technique to correct the standard errors using STATA 13 (2013).

\section{Summary Statistics}

To examine the representativeness of our sample, the demographics of our data were compared with data from the US Census and American Community Survey for the City of Columbia (U.S. Census Bureau 2010-2014). In particular, we compared education level, income, and age of homeowners (see Table 1). Educational attainment is quite high in Columbia (54.5 percent with

\footnotetext{
1 We applied the bivariate probit model (data not shown) to test this correlation by joint prediction of adoption choices. The results showed that rho $(\rho)$ was significant at the 1-percent level and very close to 1 , so adoption decisions of rain gardens and rain barrels are not independent. Six respondents had adopted both practices.
} 
Table 1. City of Columbia American Community Survey (ACS) Demographics Versus Hinkson Creek Survey Demographics

*City of Columbia-ACS (\%) $\quad$ Hinkson Creek survey (\%)

Education

High school graduate or higher

93.1

98.97

Bachelor's degree or higher

54.5

68.81

Household income

Less than $\$ 50,000$

55

26

$\$ 50,000-\$ 74,999$

15

27

$\$ 75,000-\$ 99,999$

10

18

More than $\$ 100,000$

20

29

Homeowner Age: 45 and up

63.4

66.8

*Source: U.S. Census Bureau, 2009-2013 5-Year American Community Survey.

bachelor's degree or higher in the census, vs. 68.8 percent of survey respondents) because the University of Missouri's main campus is located there. Low-income households were underrepresented among respondents; there were fewer in the category with household income less than $\$ 50,000$ (55 percent in the census, vs. 26 percent of survey respondents) and more in other categories. The percent of residents who were more than 45 years old is 63.4 percent vs. 66.8 percent in our survey. Because the Census data include households living in condos and apartments, as well as those in single-family homes, Census statistics would be expected to contain lower education levels, lower income levels, and younger ages than our respondents, because those who live in houses tend to be older and more educated and have higher incomes (Gyourko and Linneman 1997, Groves 2016). This comparison shows that our sample of respondents is reasonably representative of households with yards in the City of Columbia.

Summary statistics for the 783 observation dataset can be found in Table 2 . These statistics are also presented separately for adopters and nonadopters. Only 3.12 percent and 7.47 percent of respondents are currently using rain gardens and rain barrels, respectively, similar to results found in the Chesapeake Bay, at 2.3 percent and 7.6 percent (Newburn et al. 2014). Comparing the different categories of nonadopters, it is obvious that the awareness of rain gardens is much lower than that of rain barrels.

Some of the variables are analyzed further. Note that the percentages for categories in a column sum to 100, e.g., of those who had never heard of rain gardens, 36 percent were over 60 years old, while among those who had never heard of rain barrels, only 15 percent were over 60 . The percentages of those who had never heard of rain gardens in each age category were similar to their representation in respondents, but for rain barrels, younger people 
Table 2. Summary Statistics

\begin{tabular}{|c|c|c|c|c|c|c|c|c|c|c|}
\hline \multirow[b]{3}{*}{ Variables $^{\text {a) }}$} & \multirow[b]{3}{*}{$\begin{array}{c}\text { Overall } \\
\text { Mean }\end{array}$} & \multirow[b]{3}{*}{$\begin{array}{l}\text { Std. } \\
\text { Dev. }\end{array}$} & \multicolumn{4}{|c|}{ Rain garden } & \multicolumn{4}{|c|}{ Rain barrel } \\
\hline & & & \multirow[b]{2}{*}{ Adopters } & \multicolumn{3}{|c|}{ Nonadopters } & \multirow[b]{2}{*}{ Adopters } & \multicolumn{3}{|c|}{ Nonadopters } \\
\hline & & & & $\begin{array}{c}\text { Never } \\
\text { Heard } \\
\text { of it }\end{array}$ & $\begin{array}{c}\text { Know } \\
\text { Somewhat }\end{array}$ & $\begin{array}{c}\text { Know } \\
\text { well }\end{array}$ & & $\begin{array}{c}\text { Never } \\
\text { Heard } \\
\text { of it }\end{array}$ & $\begin{array}{c}\text { Know } \\
\text { Somewhat }\end{array}$ & $\begin{array}{c}\text { Know } \\
\text { well }\end{array}$ \\
\hline Dependent Variables & & & $3 \%$ & $39 \%$ & $38 \%$ & $20 \%$ & $8 \%$ & $7 \%$ & $42 \%$ & $43 \%$ \\
\hline \multicolumn{11}{|l|}{ Independent Variables $^{\text {b) }}$} \\
\hline \multicolumn{11}{|l|}{ Personal Characteristics } \\
\hline \multicolumn{11}{|l|}{ Household Income } \\
\hline$\$ 0-\$ 25,000$ & 0.079 & 0.269 & $9 \%$ & $8 \%$ & $8 \%$ & $5 \%$ & $4 \%$ & $13 \%$ & $8 \%$ & $6 \%$ \\
\hline$\$ 25,000-\$ 49,999$ & 0.199 & 0.400 & $17 \%$ & $22 \%$ & $18 \%$ & $19 \%$ & $21 \%$ & $30 \%$ & $18 \%$ & $20 \%$ \\
\hline$\$ 50,000-\$ 74,999$ (base) & 0.262 & 0.440 & $39 \%$ & $25 \%$ & $25 \%$ & $28 \%$ & $29 \%$ & $20 \%$ & $24 \%$ & $30 \%$ \\
\hline$\$ 75,000-\$ 99,999$ & 0.173 & 0.378 & $9 \%$ & $19 \%$ & $17 \%$ & $16 \%$ & $14 \%$ & $9 \%$ & $19 \%$ & $18 \%$ \\
\hline$\$ 100,000+$ & 0.288 & 0.453 & $26 \%$ & $25 \%$ & $31 \%$ & $33 \%$ & $32 \%$ & $28 \%$ & $31 \%$ & $27 \%$ \\
\hline \multicolumn{11}{|l|}{ Age } \\
\hline $18-30 \mathrm{yrs}$ & 0.084 & 0.277 & $8 \%$ & $10 \%$ & $7 \%$ & $7 \%$ & $5 \%$ & $17 \%$ & $6 \%$ & $10 \%$ \\
\hline $31-45$ yrs & 0.248 & 0.432 & $8 \%$ & $23 \%$ & $27 \%$ & $27 \%$ & $32 \%$ & $28 \%$ & $21 \%$ & $27 \%$ \\
\hline 46-60 yrs (base) & 0.307 & 0.462 & $21 \%$ & $31 \%$ & $29 \%$ & $34 \%$ & $29 \%$ & $40 \%$ & $33 \%$ & $28 \%$ \\
\hline$>60 \mathrm{yrs}$ & 0.360 & 0.480 & $63 \%$ & $36 \%$ & $36 \%$ & $31 \%$ & $34 \%$ & $15 \%$ & $40 \%$ & $35 \%$ \\
\hline Male & 0.635 & 0.482 & $71 \%$ & $59 \%$ & $63 \%$ & $72 \%$ & $64 \%$ & $64 \%$ & $62 \%$ & $65 \%$ \\
\hline \multicolumn{11}{|l|}{ Where you live } \\
\hline Urban area (base) & 0.622 & 0.485 & $79 \%$ & $59 \%$ & $64 \%$ & $62 \%$ & $51 \%$ & $63 \%$ & $64 \%$ & $61 \%$ \\
\hline Suburban area & 0.238 & 0.426 & $17 \%$ & $28 \%$ & $22 \%$ & $19 \%$ & $18 \%$ & $29 \%$ & $24 \%$ & $24 \%$ \\
\hline Rural area & 0.140 & 0.347 & $4 \%$ & $13 \%$ & $14 \%$ & $19 \%$ & $32 \%$ & $8 \%$ & $11 \%$ & $15 \%$ \\
\hline
\end{tabular}




\begin{tabular}{|c|c|c|c|c|c|c|c|c|c|c|}
\hline \multirow[b]{3}{*}{ Variables $^{a}$} & \multirow[b]{3}{*}{$\begin{array}{c}\text { Overall } \\
\text { Mean }\end{array}$} & \multirow[b]{3}{*}{$\begin{array}{l}\text { Std. } \\
\text { Dev. }\end{array}$} & \multicolumn{4}{|c|}{ Rain garden } & \multicolumn{4}{|c|}{ Rain barrel } \\
\hline & & & \multirow[b]{2}{*}{ Adopters } & \multicolumn{3}{|c|}{ Nonadopters } & \multirow[b]{2}{*}{ Adopters } & \multicolumn{3}{|c|}{ Nonadopters } \\
\hline & & & & $\begin{array}{c}\text { Never } \\
\text { Heard } \\
\text { of it }\end{array}$ & $\begin{array}{c}\text { Know } \\
\text { Somewhat }\end{array}$ & $\begin{array}{c}\text { Know } \\
\text { well }\end{array}$ & & $\begin{array}{c}\text { Never } \\
\text { Heard } \\
\text { of it }\end{array}$ & $\begin{array}{c}\text { Know } \\
\text { Somewhat }\end{array}$ & $\begin{array}{c}\text { Know } \\
\text { well }\end{array}$ \\
\hline \multicolumn{11}{|l|}{ Yard Management Behavior } \\
\hline \multicolumn{11}{|l|}{ Hours spent on gardening/lawn } \\
\hline More than 10 hours & 0.458 & 0.498 & $67 \%$ & $36 \%$ & $47 \%$ & $60 \%$ & $75 \%$ & $25 \%$ & $38 \%$ & $53 \%$ \\
\hline \multicolumn{11}{|l|}{ Lawn watering habits } \\
\hline As needed to keep green & 0.215 & 0.411 & $30 \%$ & $23 \%$ & $19 \%$ & $18 \%$ & $13 \%$ & $36 \%$ & $26 \%$ & $16 \%$ \\
\hline Infrequently (base) & 0.380 & 0.486 & $26 \%$ & $38 \%$ & $40 \%$ & $36 \%$ & $41 \%$ & $28 \%$ & $38 \%$ & $39 \%$ \\
\hline Never/Severe drought & 0.356 & 0.479 & $26 \%$ & $35 \%$ & $36 \%$ & $40 \%$ & $39 \%$ & $36 \%$ & $31 \%$ & $39 \%$ \\
\hline Use lawn care service & 0.312 & 0.464 & $30 \%$ & $35 \%$ & $31 \%$ & $23 \%$ & $16 \%$ & $34 \%$ & $38 \%$ & $26 \%$ \\
\hline \multicolumn{11}{|c|}{ Environmental Knowledge and Attitudes } \\
\hline Knowledge of watershed term & 0.618 & 0.486 & $83 \%$ & $40 \%$ & $69 \%$ & $89 \%$ & $79 \%$ & $20 \%$ & $51 \%$ & $76 \%$ \\
\hline Trust env. group very much & 0.170 & 0.376 & $30 \%$ & $13 \%$ & $17 \%$ & $23 \%$ & $29 \%$ & $16 \%$ & $16 \%$ & $16 \%$ \\
\hline $\begin{array}{l}\text { Concern about neighbors' } \\
\text { opinion }\end{array}$ & 0.375 & 0.484 & $38 \%$ & $40 \%$ & $37 \%$ & $33 \%$ & $33 \%$ & $42 \%$ & $40 \%$ & $35 \%$ \\
\hline Concern about intense rain & 0.359 & 0.480 & $42 \%$ & $31 \%$ & $40 \%$ & $34 \%$ & $37 \%$ & $38 \%$ & $32 \%$ & $39 \%$ \\
\hline Concern about severe drought & 0.763 & 0.425 & $75 \%$ & $80 \%$ & $74 \%$ & $72 \%$ & $81 \%$ & $79 \%$ & $76 \%$ & $76 \%$ \\
\hline \multicolumn{11}{|c|}{ Perception of Limitations of Rain Gardens } \\
\hline Cost required & 0.465 & 0.499 & $33 \%$ & $36 \%$ & $54 \%$ & $54 \%$ & & & & \\
\hline Time required & 0.467 & 0.499 & $27 \%$ & $38 \%$ & $57 \%$ & $46 \%$ & & & & \\
\hline Lack of equipment & 0.386 & 0.487 & $9 \%$ & $34 \%$ & $49 \%$ & $33 \%$ & & & & \\
\hline Concerns about appearance & 0.311 & 0.463 & $18 \%$ & $31 \%$ & $36 \%$ & $23 \%$ & & & & \\
\hline Doubt the benefits & 0.172 & 0.377 & $5 \%$ & $15 \%$ & $20 \%$ & $19 \%$ & & & & \\
\hline
\end{tabular}


Table 2. Continued

\begin{tabular}{|c|c|c|c|c|c|c|c|c|c|c|}
\hline \multirow[b]{3}{*}{ Variables ${ }^{\text {a) }}$} & \multirow[b]{3}{*}{$\begin{array}{l}\text { Overall } \\
\text { Mean }\end{array}$} & \multirow[b]{3}{*}{$\begin{array}{l}\text { Std. } \\
\text { Dev. }\end{array}$} & \multicolumn{4}{|c|}{ Rain garden } & \multicolumn{4}{|c|}{ Rain barrel } \\
\hline & & & \multirow[b]{2}{*}{ Adopters } & \multicolumn{3}{|c|}{ Nonadopters } & \multirow[b]{2}{*}{ Adopters } & \multicolumn{3}{|c|}{ Nonadopters } \\
\hline & & & & $\begin{array}{c}\text { Never } \\
\text { Heard } \\
\text { of it }\end{array}$ & $\begin{array}{c}\text { Know } \\
\text { Somewhat }\end{array}$ & $\begin{array}{c}\text { Know } \\
\text { well }\end{array}$ & & $\begin{array}{c}\text { Never } \\
\text { Heard } \\
\text { of it }\end{array}$ & $\begin{array}{c}\text { Know } \\
\text { Somewhat }\end{array}$ & $\begin{array}{c}\text { Know } \\
\text { well }\end{array}$ \\
\hline $\begin{array}{l}\text { Compatibility with other } \\
\text { features }\end{array}$ & 0.378 & 0.485 & $23 \%$ & $23 \%$ & $44 \%$ & $58 \%$ & & & & \\
\hline Physical/ health limitation & 0.215 & 0.411 & $5 \%$ & $21 \%$ & $24 \%$ & $20 \%$ & & & & \\
\hline Water problem in basement & 0.130 & 0.337 & $27 \%$ & $9 \%$ & $15 \%$ & $15 \%$ & & & & \\
\hline $\begin{array}{l}\text { Not able to see a } \\
\text { demonstration }\end{array}$ & 0.346 & 0.476 & $5 \%$ & $45 \%$ & $37 \%$ & $16 \%$ & & & & \\
\hline Lack knowledge of installing & 0.462 & 0.499 & $14 \%$ & $50 \%$ & $53 \%$ & $32 \%$ & & & & \\
\hline \multicolumn{11}{|c|}{ Perception of Limitations of Rain Barrels } \\
\hline Cost required & 0.429 & 0.495 & & & & & $15 \%$ & $29 \%$ & $48 \%$ & $46 \%$ \\
\hline Time required & 0.308 & 0.462 & & & & & $2 \%$ & $33 \%$ & $40 \%$ & $26 \%$ \\
\hline Lack of equipment & 0.452 & 0.498 & & & & & $5 \%$ & $41 \%$ & $53 \%$ & $46 \%$ \\
\hline Concerns about appearance & 0.271 & 0.444 & & & & & $4 \%$ & $31 \%$ & $33 \%$ & $26 \%$ \\
\hline Doubt the benefits ${ }^{c}$ & 0.173 & 0.378 & & & & & $0 \%$ & $10 \%$ & $21 \%$ & $19 \%$ \\
\hline $\begin{array}{l}\text { Compatibility with other } \\
\text { features }\end{array}$ & 0.258 & 0.438 & & & & & $9 \%$ & $17 \%$ & $28 \%$ & $27 \%$ \\
\hline Physical/ health limitation & 0.209 & 0.407 & & & & & $11 \%$ & $21 \%$ & $29 \%$ & $15 \%$ \\
\hline Water problem in basement & 0.098 & 0.298 & & & & & $9 \%$ & $6 \%$ & $9 \%$ & $11 \%$ \\
\hline $\begin{array}{l}\text { Not able to see a } \\
\text { demonstration }\end{array}$ & 0.271 & 0.445 & & & & & $4 \%$ & $27 \%$ & $41 \%$ & $18 \%$ \\
\hline Lack knowledge of installing & 0.308 & 0.462 & & & & & $2 \%$ & $37 \%$ & $50 \%$ & $17 \%$ \\
\hline
\end{tabular}

a) Total number of observations is 768 .

b) For all the independent variables, the range is $0-1$.

c) The variable "Doubt the benefits" is not included in our subsequent regression model because no adopters indicated they doubted the benefits. 
were more likely to have never heard of the practice. Interestingly, a higher proportion of adopters of rain gardens (79 percent) are in urban areas compared to adopters of rain barrels (51 percent), but a much lower proportion of rain garden adopters (4 percent) are in rural areas than adopters of rain barrels (32 percent).

Almost half of respondents (45 percent) spend more than 10 hours on gardening or lawn care in a month during the growing season between March and November. Interestingly, over a third of these respondents were not aware of rain gardens and over one quarter had not heard of rain barrels, but in general those with more knowledge spent more time gardening. Respondents who are concerned about intense rain and severe drought are 36 percent and 76 percent, respectively, which may relate to the drought in 2012.

Major limitations of adoption of rain gardens include cost, time required, and knowledge of installing the practice (46.7 percent, 46.5 percent, and 46.2 percent, respectively). Interestingly, the perceived cost and time required were less of a barrier for those who had never heard of the practice, than for nonadopters that were familiar with it. This was also the case for compatibility with other features. In all cases except a water problem in the basement, nonadopters viewed these factors as more of a barrier to rain gardens than adopters.

On the other hand, for key limitations of adoption of rain barrels, lack of equipment and cost are most important for survey respondents (45.2 percent and 42.9 percent, respectively). For rain barrels, nonadopters viewed all factors as more of a barrier than adopters, except in the case of a water problem in the basement, similar to the case for rain gardens. Note that none of the adopters doubted the water quality benefits of rain barrels.

From Table 2, we see evidence that in general, nonadopters are different from adopters in demographic characteristics, yard management behavior, environmental knowledge and attitudes, and their perceptions of barriers regarding specific practices. Moreover, those who have never heard of specific practices are quite different from those who know the practices well but do not use them, with regard to several variables. In particular, for rain gardens, there is a gap between the aforementioned populations in the variables of hours spent on gardening (36 percent vs 60 percent), knowledge of watershed (40 percent vs 89 percent), perceptions of limitations of rain garden such as cost (36 percent vs 54 percent), time (38 percent vs 46 percent), compatibility with other features (23 percent vs 58 percent), demonstration (45 percent vs 16 percent), and knowledge of installing (50 percent vs 32 percent). For rain barrels, we observe this with hours spent on gardening ( 25 percent vs 53 percent), watering as needed (36 percent vs 16 percent), knowledge of watershed ( 20 percent vs 76 percent), perceptions of limitations of rain barrels such as cost (29 percent vs 46 percent), and knowledge of installing (37 percent vs 17 percent). In other words, there may be important differences between the various categories of nonadopters which should be considered when developing educational programs. While 
the summary statistics provide some information on perceived barriers, and differences between adopters and different types of nonadopters, regression analyses are used to rigorously examine our research questions.

\section{Regression Results}

Tables 3 and 4 present the estimated coefficients and significance levels from the MNLs for rain gardens and rain barrels, respectively. We use the multinomial model with adopters as the base and the other response categories of nonadopters who: never heard of it, know somewhat, or know well about, each practice as the dependent variables. Care should be taken in interpreting the coefficients because they indicate whether or not the respondents who provide answers (e.g., male versus the base of female) are more or less likely to be in a particular nonadopter category compared to being an adopter. In other words, a negative coefficient means that particular variable is positively associated with adoption.

In reviewing the correlation matrix for multicollinearity, there is little evidence of a problem because none of the correlations was higher than 0.5 among variables except time required and cost required (0.62) for rain gardens. Also, multicollinearity for the independent variables was checked using the variance inflation factor (VIF). The VIF for all variables in the models was less than 2.21, which was below the cutoff minimum of 10 suggested by Hair et al. (2006). Hence, no evidence of multicollinearity in the regressions is found.

To aid in the comparison of model performance due to including the perceptions of each practice, pseudo- $\mathrm{R}^{2}$ values can be calculated for the goodness-of-fit of the model. An increasing pseudo- $\mathrm{R}^{2}$ may indicate a better fit, but no simple interpretation similar to the $R^{2}$ of the linear regression model is possible (Long and Freese 2006). Nevertheless, the pseudo- $\mathrm{R}^{2}$ values would be valid and useful for comparing models because all models predict the same outcome on the same data (Long and Freese 2006). For both practices, the McFadden pseudo- $\mathrm{R}^{2}$ values in the full model $(0.222$ for rain gardens, 0.265 for rain barrels) are much higher than in the reduced model ( 0.120 for rain gardens, 0.130 for rain barrels). As expected, because the data contain a high proportion of 0 observations for the dependent variable, the goodness-of-fit values are not expected to be very high (Keelan et al. 2009). Also, the Akaike information criterion (AIC) and Bayesian information criterion (BIC) are used to measure the relative quality of statistical models given a data set, and because the AIC and BIC values in the full models are lower than in the reduced models (see tables 3 and 4), the full model has more explanatory power in both cases. The likelihood ratio test for all four models has a small $p$-value $(p<0.01)$. The full models correctly classified 98 percent of rain garden adopters and 92 percent of rain barrel adopters. 


\section{Rain garden results}

Estimation results for rain gardens are reported in Table 3. The rain garden results for income are particularly interesting. In the reduced model, only one income coefficient is significant; respondents who are in the $\$ 75,000$ $\$ 99,999$ income category rather than the base category of $\$ 50,000-74,999$ are more likely to have never heard of the practice than to be adopters of rain gardens, holding other variables constant. In the full model that included perception variables, other significant income results are observed. If respondents earn $\$ 75,000-\$ 99,999$ rather than the base category, they are significantly $(\mathrm{p}<0.01)$ more likely to be in one of the nonadopter categories rather than being adopters, and the magnitude of the effect is quite large. This is also true for those earning more than $\$ 100,000$, although both the significance and magnitudes are less. Taken together, these findings are inconsistent with previous work concluding that financial resources are importantly and positively correlated to adoption ${ }^{2}$ (Ando and Freitas 2011, Brehm, Pasko, and Eisenhauer 2013). On the other hand, the opportunity cost of adoption may be higher for these high-income categories. There is no significant effect of gender and only one significant variable for age; in the reduced model, respondents over 61 were less likely than those aged 46-60 to be well-informed nonadopters than to be adopters. In the reduced model, suburbanites are more likely to have never heard of rain gardens than those in urban areas.

Yard management variables such as time spent on gardening and watering habits are significant predictors of adoption in both models. For example, those who spent more than 10 hours per month on gardening were significantly less likely to either have never heard of rain gardens or know the practice only somewhat, than to be adopters of rain gardens. This is in line with previous studies, many of which find a positive correlation between homeowners who are interested in gardening and the probability of adoption of stormwater or lawn management practices (Newburn et al. 2014, Martini et al. 2015). However, time spent gardening is not significantly different between people who know the practice well and those who adopt this practice. That is, serious gardeners are aware of rain gardens but may not adopt.

Watering habits are closely related to rain garden adoption. In the full model, those who water their lawn frequently versus infrequently are less likely to be nonadopters of rain gardens $(\mathrm{p}<0.05)$. Put another way, there is evidence that adopters tend to want a green lawn.

Our results support the findings that those who are well informed about watersheds are more likely to adopt stormwater management (Brehm, Pasko, and Eisenhauer 2013, Martini and Nelson 2014) and those with

2 In a bivariate model comparing all types of nonadopters to adopters, similar results were found regarding higher income levels. 
Table 3. Rain Garden Multinomial Regression Results with Adopt as the Base

\begin{tabular}{|c|c|c|c|c|c|c|}
\hline & \multicolumn{3}{|c|}{ Reduced Model Coef. } & \multicolumn{3}{|c|}{ Full Model Coef. } \\
\hline & $\begin{array}{l}\text { Never heard } \\
\text { of it }\end{array}$ & $\begin{array}{c}\text { Know } \\
\text { somewhat }\end{array}$ & $\begin{array}{c}\text { Know } \\
\text { well }\end{array}$ & $\begin{array}{c}\text { Never heard } \\
\text { of it }\end{array}$ & $\begin{array}{c}\text { Know } \\
\text { somewhat }\end{array}$ & $\begin{array}{c}\text { Know } \\
\text { well }\end{array}$ \\
\hline \multicolumn{7}{|c|}{ Personal Characteristics } \\
\hline \multicolumn{7}{|c|}{ Household Income (Base: \$50,000-\$74,999) } \\
\hline$\$ 0-\$ 24,999$ & -0.199 & -0.123 & -0.220 & -0.133 & -0.122 & -0.109 \\
\hline$\$ 25,000-\$ 49,999$ & 0.872 & 0.486 & 0.496 & 1.701 & 1.107 & 1.385 \\
\hline$\$ 75,000-\$ 99,999$ & $1.399^{*}$ & 1.196 & 0.747 & $3.262^{* * *}$ & $2.890^{* * *}$ & $2.493^{* * *}$ \\
\hline$\$ 100,000+$ & 0.494 & 0.608 & 0.464 & $1.941^{* *}$ & $2.068^{* *}$ & $2.017^{* *}$ \\
\hline \multicolumn{7}{|l|}{ Age (Base: 46-60 yrs) } \\
\hline $18-30$ yrs & -0.735 & -0.619 & -0.248 & 0.570 & 0.424 & 0.761 \\
\hline $31-45$ yrs & 0.142 & 0.578 & 0.647 & 1.678 & 2.243 & 2.241 \\
\hline$>61 \mathrm{yrs}$ & -0.793 & -0.699 & $-1.025^{*}$ & -0.827 & -0.627 & -0.979 \\
\hline Male & -0.335 & -0.212 & 0.165 & 0.486 & 0.524 & 0.824 \\
\hline \multicolumn{7}{|c|}{ Where you live (Base: Urban area) } \\
\hline Suburban area & $1.212^{*}$ & 0.843 & 0.314 & 0.684 & 0.482 & 0.075 \\
\hline Rural area & 1.102 & 1.370 & 1.353 & 1.626 & 1.831 & 1.663 \\
\hline \multicolumn{7}{|c|}{ Yard Management Behavior } \\
\hline \multicolumn{7}{|c|}{ Hours spent on gardening/lawn (Base: less than 10 hrs) } \\
\hline More than $10 \mathrm{hrs}$ & $-1.17^{* *}$ & $-0.997^{*}$ & -0.481 & $-1.911^{* * *}$ & $-1.803^{* *}$ & -1.192 \\
\hline
\end{tabular}


Table 3. Continued

\begin{tabular}{|c|c|c|c|c|c|c|}
\hline & \multicolumn{3}{|c|}{ Reduced Model Coef. } & \multicolumn{3}{|c|}{ Full Model Coef. } \\
\hline & $\begin{array}{c}\text { Never heard } \\
\text { of it }\end{array}$ & $\begin{array}{c}\text { Know } \\
\text { somewhat }\end{array}$ & $\begin{array}{c}\text { Know } \\
\text { well }\end{array}$ & $\begin{array}{c}\text { Never heard } \\
\text { of it }\end{array}$ & $\begin{array}{c}\text { Know } \\
\text { somewhat }\end{array}$ & $\begin{array}{l}\text { Know } \\
\text { well }\end{array}$ \\
\hline \multicolumn{7}{|l|}{ Lawn watering habits (Base: infrequently) } \\
\hline As needed to keep green & -0.587 & $-0.896^{*}$ & -0.594 & $-1.816^{* * *}$ & $-2.03^{* * *}$ & $-1.594^{* *}$ \\
\hline Never/ Severe drought & 0.390 & 0.335 & 0.511 & 1.750 & 1.668 & $1.865^{*}$ \\
\hline Use lawn care service & 0.406 & 0.093 & -0.095 & 0.335 & 0.098 & 0.048 \\
\hline \multicolumn{7}{|l|}{ Environmental Knowledge and Attitudes } \\
\hline Knowledge of watershed term & $-1.756^{* * *}$ & -0.627 & 0.584 & $-1.816^{*}$ & -0.669 & 0.326 \\
\hline Trust environmental group very much & $-1.048^{*}$ & -0.812 & -0.067 & $-2.291^{*}$ & -2.093 & -1.288 \\
\hline Concern about neighbors' opinion & -0.058 & 0.050 & -0.009 & 0.703 & 0.710 & 0.801 \\
\hline Concern about intense rain & -0.577 & -0.143 & -0.616 & -0.886 & -0.417 & -0.837 \\
\hline Concern about severe drought & 0.881 & 0.324 & 0.297 & 1.582 & 1.072 & 0.911 \\
\hline \multicolumn{7}{|c|}{ Perception of Limitations of Specific Practices } \\
\hline Cost required & & & & -2.566 & -2.422 & -1.844 \\
\hline Time required & & & & -0.537 & 0.243 & -0.132 \\
\hline Lack of equipment & & & & 0.655 & 1.236 & 0.979 \\
\hline Concerns about appearance & & & & 1.224 & 1.287 & 0.590 \\
\hline Compatibility with other features & & & & 0.954 & 1.597 & 2.084 \\
\hline Physical/health limitation & & & & 2.902 & 2.769 & $2.932^{*}$ \\
\hline
\end{tabular}


Table 3. Continued

\begin{tabular}{|c|c|c|c|c|c|c|}
\hline & \multicolumn{3}{|c|}{ Reduced Model Coef. } & \multicolumn{3}{|c|}{ Full Model Coef. } \\
\hline & $\begin{array}{c}\text { Never heard } \\
\text { of it }\end{array}$ & $\begin{array}{c}\text { Know } \\
\text { somewhat }\end{array}$ & $\begin{array}{c}\text { Know } \\
\text { well }\end{array}$ & $\begin{array}{c}\text { Never heard } \\
\text { of it }\end{array}$ & $\begin{array}{c}\text { Know } \\
\text { somewhat }\end{array}$ & $\begin{array}{c}\text { Know } \\
\text { well }\end{array}$ \\
\hline Concerns about water problem in basem & ent & & & $-3.326^{* * *}$ & $-3.072^{* * *}$ & $-2.739^{* * *}$ \\
\hline Not able to see a demonstration & & & & $3.781^{*}$ & 3.055 & 2.151 \\
\hline Lack knowledge of installing & & & & $3.382^{*}$ & 2.997 & 2.414 \\
\hline Constant & $3.702^{* * *}$ & $3.347^{* * *}$ & 1.458 & 1.927 & 1.286 & -0.197 \\
\hline \multicolumn{7}{|l|}{ Goodness of fit } \\
\hline$N$ & & 657 & & & 596 & \\
\hline Wald chi2 (87) & & 214.98 & & & 258.49 & \\
\hline Prob $>$ chi2 & & 0 & & & 0 & \\
\hline Log pseudolikelihood & & -674.99 & & & -539.48 & \\
\hline Pseudo R2 & & 0.1200 & & & 0.2219 & \\
\hline$A I C$ & & 1378.18 & & & 1154.93 & \\
\hline$B I C(d f=60)$ & & 1646.89 & & & 1537.17 & \\
\hline
\end{tabular}

Notes: Superscripts ${ }^{*},{ }^{* *}$ and ${ }^{* * *}$ indicate statistical significance at the 10 percent, 5 percent and 1 percent levels, respectively. 
Table 4. Rain Barrels Multinomial Regression Results with Adopt as the Base

\begin{tabular}{|c|c|c|c|c|c|c|}
\hline & \multicolumn{3}{|c|}{ Reduced Model Coef. } & \multicolumn{3}{|c|}{ Full Model Coef. } \\
\hline & $\begin{array}{c}\text { Never heard } \\
\text { of it }\end{array}$ & $\begin{array}{c}\text { Know } \\
\text { somewhat }\end{array}$ & $\begin{array}{c}\text { Know } \\
\text { well }\end{array}$ & $\begin{array}{c}\text { Never heard } \\
\text { of it }\end{array}$ & $\begin{array}{c}\text { Know } \\
\text { somewhat }\end{array}$ & $\begin{array}{c}\text { Know } \\
\text { well }\end{array}$ \\
\hline \multicolumn{7}{|l|}{ Personal Characteristics } \\
\hline \multicolumn{7}{|c|}{ Household Income (Base: \$50,000-\$74,999) } \\
\hline$\$ 0-\$ 24,999$ & 1.385 & 0.629 & 0.067 & 1.900 & 0.630 & -0.026 \\
\hline$\$ 25,000-\$ 49,999$ & $1.525^{* *}$ & 0.355 & 0.043 & $2.128^{* *}$ & 0.465 & -0.332 \\
\hline$\$ 75,000-\$ 99,999$ & -0.033 & 0.449 & 0.087 & 0.933 & 0.682 & -0.020 \\
\hline$\$ 100,000+$ & 0.082 & 0.005 & -0.379 & 0.408 & 0.247 & -0.342 \\
\hline \multicolumn{7}{|l|}{ Age (Base: 46-60 yrs) } \\
\hline $18-30$ yrs & -0.155 & -0.513 & 0.419 & 0.092 & -0.452 & 0.272 \\
\hline $31-45$ yrs & $-1.160^{* *}$ & $-0.815^{* *}$ & -0.411 & $-1.518^{* *}$ & $-1.095^{* *}$ & -0.703 \\
\hline$>60 \mathrm{yrs}$ & $-1.421^{* *}$ & 0.087 & -0.063 & $-1.428^{*}$ & -0.051 & 0.052 \\
\hline Male & 0.677 & -0.092 & -0.009 & $1.274^{* *}$ & 0.208 & 0.324 \\
\hline \multicolumn{7}{|c|}{ Where you live (Base: Urban area) } \\
\hline Suburban area & 0.399 & 0.092 & 0.064 & 0.003 & -0.024 & -0.102 \\
\hline Rural area & $-1.400^{*}$ & $-0.97^{* *}$ & $-1.093^{* * *}$ & -1.119 & -0.526 & $-0.840^{*}$ \\
\hline \multicolumn{7}{|l|}{ Yard Management Behavior } \\
\hline \multicolumn{7}{|c|}{ Hours spent on gardening/lawn (Base: less than 10 hrs) } \\
\hline More than $10 \mathrm{hrs}$ & $-1.996^{* * *}$ & $-1.366^{* * *}$ & $-0.905^{* *}$ & $-1.677^{* * *}$ & $-1.222^{* * *}$ & $-0.723^{*}$ \\
\hline \multicolumn{7}{|c|}{ Lawn watering habits (Base: infrequently) } \\
\hline As needed to keep green & $1.633^{* *}$ & 0.599 & -0.010 & $1.715^{* *}$ & 0.590 & 0.084 \\
\hline
\end{tabular}


Table 4. Continued

\begin{tabular}{|c|c|c|c|c|c|c|}
\hline & \multicolumn{3}{|c|}{ Reduced Model Coef. } & \multicolumn{3}{|c|}{ Full Model Coef. } \\
\hline & $\begin{array}{l}\text { Never heard } \\
\text { of it }\end{array}$ & $\begin{array}{c}\text { Know } \\
\text { somewhat }\end{array}$ & $\begin{array}{c}\text { Know } \\
\text { well }\end{array}$ & $\begin{array}{l}\text { Never heard } \\
\text { of it }\end{array}$ & $\begin{array}{c}\text { Know } \\
\text { somewhat }\end{array}$ & $\begin{array}{c}\text { Know } \\
\text { well }\end{array}$ \\
\hline Never/Severe drought & 0.189 & 0.069 & 0.077 & 0.047 & 0.097 & 0.031 \\
\hline Use lawn care service & 0.771 & $0.794^{*}$ & 0.470 & $1.283^{*}$ & $0.931^{*}$ & 0.556 \\
\hline \multicolumn{7}{|l|}{ Environmental Knowledge and Attitudes } \\
\hline Knowledge of watershed & $-2.542^{* * *}$ & $-0.960^{* *}$ & 0.203 & $-3.130^{* * *}$ & $-1.339^{* * *}$ & -0.282 \\
\hline $\begin{array}{l}\text { Trust environmental group very } \\
\text { much }\end{array}$ & -0.595 & $-0.779^{* *}$ & $-0.879^{* *}$ & $-1.176^{*}$ & $-0.793^{*}$ & $-0.929^{* *}$ \\
\hline Concern about neighbors' opinion & 0.212 & 0.192 & 0.113 & -0.262 & 0.061 & 0.078 \\
\hline Concern about intense rain & 0.766 & -0.081 & 0.221 & $1.379^{* *}$ & 0.387 & $0.716^{*}$ \\
\hline Concern about severe drought & -0.209 & -0.422 & -0.404 & -1.114 & $-1.351^{* *}$ & $-1.054^{* *}$ \\
\hline \multicolumn{7}{|c|}{ Perception of Limitations of Specific Practices } \\
\hline Cost required & & & & $-1.100^{*}$ & 0.343 & 0.432 \\
\hline Time required & & & & $2.834^{* *}$ & $2.223^{*}$ & $2.186^{*}$ \\
\hline Lack of equipment & & & & $2.162^{* * *}$ & $2.220^{* * *}$ & $2.666^{* * *}$ \\
\hline Concerns about appearance & & & & 1.107 & 0.891 & 1.045 \\
\hline Compatibility with other features & & & & 0.822 & $1.263^{* *}$ & $1.375^{* *}$ \\
\hline Physical/health limitation & & & & -0.974 & -1.029 & $-1.636^{* *}$ \\
\hline Concerns about water problem in $k$ & ment & & & -1.824 & -1.076 & -0.402 \\
\hline Not able to see a demonstration & & & & 0.854 & $1.682^{* *}$ & 0.871 \\
\hline
\end{tabular}


Table 4. Continued

\begin{tabular}{|c|c|c|c|c|c|c|}
\hline & \multicolumn{3}{|c|}{ Reduced Model Coef. } & \multicolumn{3}{|c|}{ Full Model Coef. } \\
\hline & $\begin{array}{l}\text { Never heard } \\
\text { of it }\end{array}$ & $\begin{array}{c}\text { Know } \\
\text { somewhat }\end{array}$ & $\begin{array}{c}\text { Know } \\
\text { well }\end{array}$ & $\begin{array}{l}\text { Never heard } \\
\text { of it }\end{array}$ & $\begin{array}{c}\text { Know } \\
\text { somewhat }\end{array}$ & $\begin{array}{c}\text { Know } \\
\text { well }\end{array}$ \\
\hline Lack knowledge of installing & & & & $2.483^{* *}$ & $2.601^{* *}$ & 0.910 \\
\hline Constant & 1.107 & $3.513^{* * *}$ & $2.815^{* * *}$ & 0.202 & $2.360^{* *}$ & $2.164^{* *}$ \\
\hline \multicolumn{7}{|l|}{ Goodness of fit } \\
\hline$N$ & & 651 & & & 598 & \\
\hline Wald chi2 (87) & & 172.87 & & & 264.88 & \\
\hline Prob $>$ chi2 & & 0 & & & 0 & \\
\hline Log pseudolikelihood & & -629.09 & & & -490.46 & \\
\hline Pseudo R2 & & 0.1301 & & & 0.2647 & \\
\hline$A I C$ & & 1378.18 & & & 1154.92 & \\
\hline$B I C(d f=60)$ & & 1646.89 & & & 1537.16 & \\
\hline
\end{tabular}

Notes: Superscripts ${ }^{*},{ }^{* *}$ and ${ }^{* * *}$ indicate statistical significance at the 10 percent, 5 percent and 1 percent levels, respectively. 
pro-environmental attitudes are more likely to adopt rain gardens (Dietz, Clausen, and Filchak 2004, Jorgensen and Syme 2000). Watershed knowledge and trusting environmental groups "very much" for information are negatively correlated with having never heard about rain gardens rather than being an adopter. There were no significant differences for other nonadopter categories. Regarding valuing neighbors' opinions on lawn care choices, contrary to Shaw et al. (2011), the effects were not significant in our research. Also, concern about intense rain and severe drought were not significant factors for nonadoption of rain gardens, in line with a study by Ando and Freitas (2011).

Several specific potential barriers to adoption of rain gardens were significant. For instance, those with physical limitations are more likely to be knowledgeable nonadopters rather than adopters $(\mathrm{p}<0.1)$. The variable "concerns about water problems in their basement" $(p<0.01)$ is negatively associated with nonadoption (or positively associated with adoption), and the coefficients are the largest for all three nonadopter models. Households adopting rain gardens might be doing so to solve water problems. This information might be used in educational materials as an important on-site benefit of the practice. The barriers of not being able to see a demonstration and need for knowledge about how to install the practice are only significant for never having heard of the practice versus adopting. These results suggest that informational campaigns on installing stormwater management practices would be most helpful if the campaigns could reach people who typically do not read about gardening. The visual characteristics of rain gardens do not seem to pose a significant barrier because appearance is not significant. These results, along with the lack of influence of neighbors' opinions, imply that social context might not be an important determinant of adoption of this practice.

\section{Rain barrels}

Table 4 provides the rain barrel results. Note that because no adopters doubted the water quality benefits of the practice, we were not able to include this important variable in our regression. Unlike rain gardens, households who are in the $\$ 25,000-\$ 49,999$ income category rather than the base category of $\$ 50,000-\$ 74,999$ are significantly more likely to have never heard of the practice than to be adopters of rain barrels, holding other variables constant, for both the reduced and full models. No other income categories are significant, so in this case the opportunity cost of time does not seem to be a barrier. In both models, respondents 31-45 years old (versus the base of 4660 years old) are significantly less likely to have never heard of rain barrels or know them only somewhat, than to be adopters. In other words, this age group is more likely to adopt. Also, if respondents are older than the base category, then they are less likely to be nonadopters who have never heard of rain barrels. Together these results (robust across models) indicate that 
awareness and adoption of rain barrels are not monotonically related to age. Male respondents are more likely to have never heard of rain barrels in the full model. Although those who live in rural areas are more likely to be rain barrel adopters in the reduced model, in the full model, the location factor is statistically significant only for those who know the practice well, and the significance is also lower. This implies that the practice-specific variables capture some factors relating to rurality. Note that in general, demographic factors do not distinguish adopters from nonadopters who know the practice well.

Similar to rain gardens, the yard management variables, such as time spent on gardening, are significant predictors of adoption. Those who spent more than 10 hours per month on gardening are more likely to adopt rain barrels in both reduced and full models, rather than being in one of the nonadopter categories. Those who water their lawn frequently (versus infrequently) are more likely to have never heard of rain barrels than to be adopters. While rain barrels are not particularly helpful for irrigating lawns because water pressure is too low to use with a sprinkler, irrigation does use a lot of water. Therefore, people who water their lawn frequently might be interested in using the water from rain barrels for their other plants, which implies that educational programs might be effective for this group. Those who use a lawn care service tend to be less knowledgeable about the practice; the "know somewhat" category is significant $(\mathrm{p}<0.1)$ in both models.

As expected, watershed knowledge is positively related to awareness of rain barrels. Those with more knowledge are less likely to have never heard of rain barrels or have a low knowledge level compared to being adopters in both reduced and full models, and this variable is also the most important one in the "never heard of it" models. Unlike the rain garden case, those with proenvironmental attitudes are more likely to adopt rain barrels, even among those who are knowledgeable about rain barrels. In the reduced model, if respondents trust environmental groups "very much" for information, they are significantly less likely to be in one of the nonadopter categories who have heard of rain barrels than to be adopters. In the full model, this is true for all nonadopter categories. In the reduced model, there is no effect of climate change concern variables. In the full model, those who are concerned about intense rain are more likely to be nonadopters who never heard of rain barrels or who know them well, than to be adopters. Those who are concerned about severe drought are less likely to be nonadopters who have heard of rain barrels, or alternatively, they are more likely to be adopters. These results imply that educational programs about rain barrels should stress them as a source of water during drought or periods without rain, which are quite common in Missouri even in normal years.

Specific barriers are examined in the full model. We found that respondents who view rain barrel costs as a barrier are less likely to be in the nonadopter category "never heard of it" than to be adopters. Unlike the cost barrier, time, and especially lack of equipment were considered to be significant and important barriers for all 
nonadopter categories. This practice requires specific equipment, and adopters obviously must have the equipment; therefore the strongly significant result, which also has fairly large magnitudes, makes sense. This result, combined with a lack of significance for the cost barrier among those at least somewhat familiar with the practice, implies that using subsidies alone may not be effective. Further research could examine whether people know where to purchase rain barrels and are able to transport them.

In addition, perceptions of compatibility with other features are significant for nonadopters who know about rain barrels. Future research, perhaps beginning with focus groups, could identify what specific compatibility issues are most important that might be used to modify the design of rain barrels. The results show there are not issues related to appearance. Interestingly, respondents who indicate a physical or health issue limits their ability to use rain barrels are less likely to be nonadopters who know the practice well than to be adopters. This implies that physical limitations are not a major barrier for this practice. The variable of not being able to see a demonstration is significantly associated with only nonadopters who know rain barrels somewhat compared to adopters, and the coefficient for this variable is also quite large. Being able to see a demonstration of the practice beforehand might make these households more likely to adopt. As expected, respondents who perceived lack of knowledge of how to install rain barrels as an adoption barrier, are more likely to be nonadopters who have never heard of rain barrels or know them somewhat, compared to adopters. It is reassuring that lack of knowledge is not a barrier for those who indicate they know how to use the practice, i.e., their responses on two sections of the survey support each other.

\section{Summary and Conclusions}

The aim of this study was to identify the determinants of stormwater management practice adoption by homeowners, to identify important barriers and thus enable targeted educational programs that increase adoption of BMPs, and to provide insights for practice or policy design. Specifically, the likelihood of being one of three types of nonadopter of rain gardens and rain barrels, compared to being an adopter, was investigated using a clustered MNL. By analyzing survey data from an urbanizing watershed in Missouri, this study found several implications for efforts to increase homeowners' adoption of practices.

Estimation results for rain gardens and rain barrels show that the most consistent factors affecting the likelihood of adoption for both practices were related to gardening activities and environmental attitudes, in line with previous studies (e.g., Purchase 1997, Newburn et al. 2014, Martini et al. 2015). The results also confirmed that the factor of a particular practice being time consuming is important. However, demographic factors seem to vary according to the specific BMPs employed. An interesting finding is that 
respondents who are concerned about water problems in their basement are more likely to adopt rain gardens. People thus may view rain gardens as a potential solution to a water problem in their yards, which is information that may be useful to educators and landscaping professionals. Our unique dataset enables us to distinguish between different types of nonadopters. Combined with the data on practice-specific barriers, we find that nonadopters with extensive knowledge about a specific practice are quite different from other nonadopter categories. Finally, including the variables relating to perceptions of an innovation's barriers can improve model performance in terms of pseudo- $\mathrm{R}^{2}$ and AIC/BIC, and more importantly, can provide useful information for practice, policy, and program design.

Based on our results, we suggest several steps to make educational programs on stormwater management more effective. First, the relative emphasis should be tailored to the audience because different people may be more motivated by onsite or off-site benefits. The research identifies both serious gardeners and concerned environmentalists as possible adopters, but also indicates that for nonadopters who know the practice well, more information is unlikely to be effective. Nevertheless, groups such as Master Gardeners, garden clubs, and local environmental organizations are easy to identify and likely to be receptive to educational programs about stormwater management practices and their onsite and off-site benefits. Rather than relying on informational materials or meetings alone, in-depth education programs, such as workshops and demonstrations on how to install rain barrels and rain gardens, may overcome inertia.

However, those who have never heard of these practices are less likely to be involved with gardening or environmental organizations and less likely to be motivated by off-site benefits. Reaching this group may be difficult, so providing informational brochures with utility bills or getting local television stations to highlight the practices may be useful. Outreach to landscaping companies and gardening stores may also be effective. The on-site benefits to the homeowner should be emphasized. Developing rain garden and rain barrel demonstrations in highly visible places, such as a public library, park, town hall, or school, should be considered because our results suggest that those who have never heard of these practices are unlikely to proactively seek out demonstration sites.

Another policy implication from this study is the importance of practicespecific barriers and benefits. An important on-site benefit of rain gardens seems to be reduction of water problems in the home. Given the potential onsite and off-site benefits of rain gardens and swales, and the low adoption rate, local policy makers may want to require them in new housing developments because it would be less costly than for individual homeowners to install them after the homes are built. For rain barrels, compatibility with other features, time, and lack of equipment were viewed as major barriers. This implies that financial incentives alone might not be effective. Delivery and set-up of rain barrels, in addition to subsidizing the 
cost, might be more effective, especially in areas of the country where people would have problems transporting the barrels.

Although this study provides some valuable insights into predictors of stormwater management practice adoption among homeowners, complementary research is needed. It would be helpful to analyze the actual response to economic incentive programs for stormwater management practices versus some interventions suggested by behavioral economics, with an aim to improve program design. For example, testing the effect of delivery and set-up of rain barrels (thus overcoming inertia, lack of knowledge, and transportation issues) could be examined. In addition, further research is needed to determine what aspects of "compatibility with other features" limit adoption of rain barrels, because modifying their design could potentially address these issues. Other practices, such as swales, depressions which are managed like normal lawns, should be evaluated, especially for people who are not interested in gardening and/or use lawn-care professionals.

\section{References}

Agresti, A. 2003. Categorical Data Analysis (2nd edition). Hoboken, NJ: John Wiley \& Sons, Inc. Amiralaei, E., A. Attieh, R. Baumann, K. Eto, and O. Ndeke. 2012. Water Management Through Rain Gardens: A Social, Environmental and Economic Analysis. UBC Social Ecological Economic Development Studies (SEEDS) Student Reports. Available at http://dx.doi. org/10.14288/1.0108325 (accessed March 2015).

Ando, A.W., and L. Freitas. 2011. "Consumer Demand for Green Stormwater Management Technology in an Urban Setting: The Case of Chicago Rain Barrels." Water Resources Research 47(12): W12501.

Armstrong, A., and R.C. Stedman. 2012. "Landowner Willingness to Implement Riparian Buffers in a Transitioning Watershed." Landscape and Urban Planning 105(3): 211-220.

Bakacs, M.E., M. Haberland, S.S. Mangiafico, A. Winquist, C.C. Obropta, A. Boyajian, and S. Mellor. 2013. "Rain Barrels: A Catalyst for Change." Journal of Extension 51(3): 3RIB6.

Barham, B.L., J.D. Foltz, D. Jackson-Smith, and S. Moon. 2004. "The Dynamics of Agricultural Biotechnology Adoption: Lessons from rBST Use in Wisconsin, 1994-2001." American Journal of Agricultural Economics 86(1): 61-72.

Baumer, M.D. 2007. "Attitudes, Awareness and Actions of the Residents of the Hinkson Creek Watershed Regarding Water Quality and Environmentalism." M.S. thesis, Department of Rural Sociology, University of Missouri-Columbia.

Blaine, T.W., S. Clayton, P. Robbins, and P.S. Grewal. 2012. "Homeowner Attitudes and Practices Towards Residential Landscape Management in Ohio, USA." Environmental Management 50(2): 257-271.

Booth, D.B. and Jackson, C.R. 1997. "Urbanization of Aquatic Systems: Degradation Thresholds, Stormwater Detection, and the Limits of Mitigation" Journal of the American Water Resources Association 22(5): 1077-1090.

Brabec, E., S. Schulte, and P.L. Richards. 2002. "Impervious Surfaces and Water Quality: A Review of Current Literature and Its Implications for Watershed Planning." Journal of Planning Literature 16(4): 499-514.

Brehm, J.M., D.K. Pasko, and B.W. Eisenhauer. 2013. "Identifying Key Factors in Homeowner's Adoption of Water Quality Best Management Practices." Environmental Management 52 (1): 113-122. 
Cary, J., T. Webb, and N.F. Barr. 2001. "The Adoption of Sustainable Practices: Some New Insights An Analysis of Drivers and Constraints for the Adoption of Sustainable Practices Derived from Research." Bureau of Rural Sciences, Canberra, Australia.

City of Chicago. 2015. Managing Stormwater at Home. Available at http://www.cityofchicago. org/content/dam/city/depts/doe/general/NaturalResourcesAndWaterConservation_PDFs/ Water/ManagingStormwater_Home.pdf (accessed January 2016)

Craig, L.S., M.A. Palmer, D.C. Richardson, S. Filoso, E.S. Bernhardt, B.P. Bledsoe, M.W. Doyle. 2008. "Stream Restoration Strategies for Reducing River Nitrogen Loads." Frontiers in Ecology and the Environment 6(10): 529-538.

DeMaio, T.J., J. Rothgeb, and J. Hess. 1998. "Improving Survey Quality through Pretesting." In Proceedings of the Section on Survey Research Methods, American Statistical Association 3: 50-58.

Dietz, M.E., J.C. Clausen, and K.K. Filchak. 2004. "Education and Changes in Residential Nonpoint Source Pollution." Environmental Management 34(5): 684-690.

Dietz, M.E. 2007. "Low Impact Development Practices: A Review of Current Research and Recommendations for Future Directions." Water, Air, and Soil Pollution 186(1-4): 351-363.

Dietz, M.E., and J.C. Clausen. 2005. "A Field Evaluation of Rain Garden Flow and Pollutant Treatment." Water, Air, and Soil Pollution 167(1-4): 123-138.

Dillman, D.A. 2011. Mail and Internet Surveys: The Tailored Design Method (2nd Edition). Hoboken, NJ: John Wiley \& Sons, Inc.

Dimara, E. and Skuras, D. 2003. "Adoption of Agricultural Innovations as a Two-Stage Partial Observability Process." Agricultural Economics 28(3): 187-196.

Feder, G., Just, R.E. and Zilberman, D. 1985. "Adoption of Agricultural Innovations in Developing Countries: A Survey." Economic Development and Cultural Change 33(2): 255-298.

Gardeners. 2015. Rainfall Harvest Calculator. Available at http://www.gardeners.com/howto/rain-barrel-how-to/5497.html (accessed September 2015)

Genskow, K., and L.S. Prokopy. 2009. "Lessons Learned in Developing Social Indicators for Regional Water Quality Management." Society \& Natural Resources 23(1): 83-91.

Gilinsky, E., M.G. Baker, J.M. Capacasa, and E.S. King. 2009. “An Urgent Call to Action-Report of the State-EPA Nutrient Innovations Task Group." In U.S. Environmental Protection Agency, Washington, D.C.

Greene, W.H. 2003. Econometric Analysis (5th Edition), Upper Saddle River, NJ: Pearson Prentice Hall.

Groves, M.A. 2016. Real estate agent, Columbia, MO. Personal communication.

Gyourko, J., and P. Linneman. 1997. "The Changing Influences of Education, Income, Family Structure, and Race on Homeownership by Age over Time." Journal of Housing Research 8(1): 1.

Hair, J.F., W.C. Black, B.J. Babin, R.E. Anderson, and R.L. Tatham. 2006. Multivariate Data Analysis. Vol. 6. Upper Saddle River, NJ: Pearson Prentice Hall.

Hinkson Creek Watershed Management Plan. 2010. Available at http://www.helpthehinkson. org/documents/WMP101111-full.pdf (accessed May, 2015)

Hosmer Jr., D.W., and S. Lemeshow. 2004. Applied Logistic Regression. Hoboken, NJ: John Wiley \& Sons, Inc.

Hudson, D., L. Seah, D. Hite, and T. Haab. 2004. "Telephone Presurveys, Self-selection, and Non-response Bias to Mail and Internet Surveys in Economic Research." Applied Economics Letters 11(4): 237-240.

Jantz, P., S. Goetz, and C. Jantz. 2005. "Urbanization and the Loss of Resource Lands in the Chesapeake Bay Watershed." Environmental Management 36(6): 808-825.

Jennings, A.A., A.A. Adeel, A. Hopkins, A.L. Litofsky, and S.W. Wellstead. 2012. "Rain BarrelUrban Garden Stormwater Management Performance." Journal of Environmental Engineering 139(5): 757-765. 
Jorgensen, B.S., and G.J. Syme. 2000. "Protest Responses and Willingness to Pay: Attitude Toward Paying for Stormwater Pollution Abatement.” Ecological Economics 33(2): 251-265.

Kaplowitz, M.D., and F. Lupi. 2012. "Stakeholder Preferences for Best Management Practices for Non-point Source Pollution and Stormwater Control." Landscape and Urban Planning 104(3): 364-372.

Keelan, C., F.S. Thorne, P. Flanagan, C. Newman, and E. Mullins. 2009. "Predicted Willingness of Irish Farmers to Adopt GM Technology." AgBioForum 12(3-4): 394-403.

Knowler, D., and B. Bradshaw. 2007. "Farmers' Adoption of Conservation Agriculture: A Review and Synthesis of Recent Research." Food Policy 32(1): 25-48.

Läpple, D., and T. Van Rensburg. 2011. "Adoption of Organic Farming: Are There Differences Between Early and Late Adoption?" Ecological Economics 70(7): 1406-1414.

Laroche, M., J. Bergeron, and G. Barbaro-Forleo. 2001. "Targeting Consumers Who Are Willing to Pay More for Environmentally Friendly Products." Journal of Consumer Marketing 18(6): 503-520.

Law, N., L. Band, and M. Grove. 2004. "Nitrogen Input from Residential Lawn Care Practices in Suburban Watersheds in Baltimore County, MD." Journal of Environmental Planning and Management 47(5): 737-755.

Li, H. and Davis, A.P. 2009. "Water Quality Improvement through Reductions of Pollutant Loads Using Bioretention." Journal of Environmental Engineering 135(8): 567-576.

Litofsky, A.L., and A.A. Jennings. 2014. "Evaluating Rain Barrel Storm Water Management Effectiveness across Climatography Zones of the United States." Journal of Environmental Engineering 140(4): 04014009.

Londoño Cadavid, C., and A.W. Ando. 2013. "Valuing Preferences Over Stormwater Management Outcomes Including Improved Hydrologic Function." Water Resources Research 49(7): 4114-4125.

Long, J.S. 1997. Regression Models for Categorical and Limited Dependent Variables. Thousand Oaks, CA: SAGE Publications.

Long, J.S., and J. Freese. 2006. Regression Models for Categorical Dependent Variables Using Stata (3rd edition). College Station, TX: Stata Press

Low Impact Development Center. 2015a. Available at http://www.lid-stormwater.net/ bio_costs.htm (accessed September 2015)

Low Impact Development Center. 2015b. Available at http://www.lid-stormwater.net/ raincist_cost.htm (accessed September 2015)

Martini, N.F., K.C. Nelson, S.E. Hobbie, and L.A. Baker. 2015. “Why 'Feed the Lawn?'” Exploring the Influences on Residential Turf Grass Fertilization in the Minneapolis-Saint Paul Metropolitan Area." Environment and Behavior 47(2): 158-183.

Martini, N.F., and K.C. Nelson. 2014. "The Role of Knowledge in Residential Lawn Management." Urban Ecosystems 18(3): 1031-1047.

Marra, M.C., B.J. Hubbell, and G.A. Carlson. 2001. "Information Quality, Technology Depreciation, and Bt Cotton Adoption in the Southeast." Journal of Agricultural and Resource Economics 26(1): 158-175.

Meyer, M.H., B.K. Behe, and J. Heilig. 2001. "The Economic Impact and Perceived Environmental Effect of Home Lawns in Minnesota." HortTechnology 11(4): 585-590.

Newburn, D., A. Alberini, A. Rockler, and A. Karp. 2014. Adoption of Household Stormwater Best Management Practices. CANRP Extension Bulletins, University of Maryland, College Park.

Pannell, D.J., G.R. Marshall, N. Barr, A. Curtis, F. Vanclay, and R. Wilkinson. 2006. "Understanding and Promoting Adoption of Conservation Practices by Rural Landholders." Animal Production Science, 46(11): 1407-1424.

Prokopy, L.S., K. Genskow, J. Asher, A. Baumgart-Getz, J. Bonnell., Broussard, S., Curtis, C., Floress, K., McDermaid, K., Power, R. and Wood, D. 2009. "Designing a Regional System of Social Indicators to Evaluate Nonpoint Source Water Projects." Journal of Extension 47(2): 8. 
Purchase, M.L. 1997. "Factors that Affect the Adoption of Lawn Alternative Residential Landscapes." Ph.D. dissertation, The University of Guelph, Ontario, CA.

Rain Garden Alliance. 2016. "How Much Does a Rain Garden Cost?" Available at http:// raingardenalliance.org/what/faqs\#cost (Accessed July 2016)

Rogers, E.M. 2010. Diffusion of Innovations (5th edition). Simon and Schuster.

Saha, A., H.A. Love, and R. Schwart. 1994. "Adoption of Emerging Technologies under Output Uncertainty." American Journal of Agricultural Economics 76: 836-846.

Shaw, B.R., B. Radler, R. Chenoweth, P. Heiberger, and P. Dearlove. 2011. "Predicting Intent to Install a Rain Garden to Protect a Local Lake: An Application of the Theory of Planned Behavior." Journal of Extension 49(4): 4FEA6.

Staab, J.M., and V.G. Iannacchione. 2003. "Evaluating the Use of Residential Mailing Addresses in a National Household Survey." In Proceedings of the Survey Research Methods Section of the American Statistical Association: 4028-4033.

STATA (software) 2013. User's Guide (Version 13). College Station, TX: Stata Press.

Stern, P. 2000. "Toward a Coherent Theory of Environmentally Significant Behavior." Journal of Social Issues 56(3): 407-424.

Swann, C.P. 2000. "A Survey of Nutrient Behavior Among Residents in the Chesapeake Bay Watershed." In Proceedings of the National Conference on Tools of Urban Water Resource Management and Protection: 230-237.

Thurston, H.W., M.A. Taylor, W.D. Shuster, A.H. Roy, and M.A. Morrison. 2010. "Using a Reverse Auction to Promote Household Level Stormwater Control." Environmental Science \& Policy 13(5): 405-414.

United Nations, Department of Economic and Social Affairs, Population Division. 2014. Highlights, World Urbanization Trends 2014: Key Facts. Available at https://esa.un. org/unpd/wup/Publications/Files/WUP2014-Highlights.pdf (accessed July 2016)

U.S. Department of Agriculture. 2013. "Summary Report: 2010 National Resources Inventory." Natural Resources Conservation Service, U.S. Department of Agriculture, Washington, D.C.

U.S. EPA, Nonpoint Source Control Branch. 2003. "Protecting Water Quality from Urban Runoff." U.S. Environmental Protection Agency, Washington, D.C. Available at http:// www3.epa.gov/npdes/pubs/nps_urban-facts_final.pdf (accessed October 2015).

U.S. EPA. 2007. "Developing Your Stormwater Pollution Prevention Plan: A Guide for Construction Sites." U.S. Environmental Protection Agency, Washington, D.C. Available at https://www3.epa.gov/npdes/pubs/sw_swppp_guide.pdf (accessed July 2016)

U.S. Census Bureau. 2010. Annual Estimates of the Resident Population: April1, 2010 to July1, 2014. Population Division. Available at http://factfinder.census.gov/faces/tableservices/ jsf/pages/productview.xhtml?src=bkmk (accessed July 2015)

U.S. Census Bureau, American Community Survey, 2010-2014 American Community Survey 5Year Estimates, Table DP04. Available at http://factfinder2.census.gov (accessed July 2015)

Van Liere, K.D., and R.E. Dunlap. 1980. "The Social Bases of Environmental Concern: A Review of Hypotheses, Explanations and Empirical Evidence." Public Opinion Quarterly 44(2): 181-197.

Varlamoff, S.M., W.J. Florkowski, J.G. Latimer, S.K. Braman, and J.L. Jordan. 2002. "Homeowners and Their Choice of Information Sources about Gardening." Journal of Extension 40(3): 3FEA7.

Varlamoff, S., W.J. Florkowski, J.L. Jordan, J. Latimer, and K. Braman. 2001. "Georgia Homeowner Survey of Landscape Management Practices." HortTechnology 11(2): 326-331.

Walker, J., and M. Ben-Akiva. 2002. “Generalized Random Utility Model.” Mathematical Social Sciences 43(3): 303-343.

Wang, L., J. Lyons, P. Kanehl, and R. Bannerman. 2001. "Impacts of Urbanization on Stream Habitat and Fish across Multiple Spatial Scales." Environmental Management 28(2): $255-266$. 